\title{
Hymnografia wieczerni święta Pięćdziesiątnicy
}

\author{
Hieromnich Paweł (Karczewski) \\ Wydział Teologiczny Chrześcijańskiej Akademii Teologicznej \\ Warszawa, Polska \\ pawel-karczewski@gazeta.pl
}

rev. P. Karczewski, Hymnography of Vespers of the Feast of the Pentecost, Elpis, 20 2018: 151-158.

\begin{abstract}
The Pentecost is one of the most important feasts in the Orthodox calendar - from the liturgical and historical points of view. Hymnography on that day touches many aspects - it presents the Orthodox Trinitarian Theology and Pneumatology. In the poetical way it also shows the event, which happened in the Cenacle. Present paper describes those liturgical texts sung and read during the festal Vespers and generally their influence on the liturgical life - there is, for example the illustrious prayer of St. Cosmas of

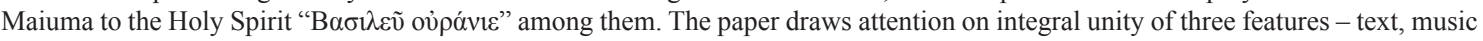
and spiritual aspect - in hymnography.

Streszczenie: Pięćdziesiątnica to jedno z najważniejszych świąt w prawosławnym kalendarzu - z punktu widzenia zarówno liturgicznego jak i historycznego. Hymnografia tego dnia porusza wiele aspektów - przedstawia prawosławną teologię trynitarną oraz pneumatologię. W poetycki sposób prezentuje także wydarzenie, które dokonało się w Wieczerniku. Prezentowany artykuł omawia teksty liturgiczne śpiewane i czytane podczas świątecznej wieczerni oraz generalnie ich wpływ na życie liturgiczne - wśród nich jest

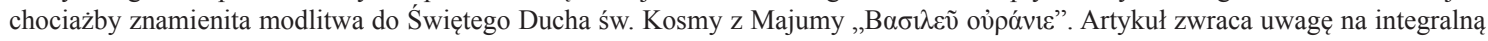
łączność w hymnografii trzech cech - tekstu, muzyki i strony duchowej.
\end{abstract}

Keywords: hymnography, vespers, Pentecost, Holy Spirit, service

Słowa kluczowe: hymnografia, wieczernia, Pięćdziesiątnica, Duch Święty, nabożeństwo

\section{Wstęp}

Pięćdziesiątnicą w prawosławnej heortologii określa się zarówno święto Zesłania Świętego Ducha na Apostołów jak i poprzedzający je pięćdziesięciodniowy okres po Zmartwychwstaniu Pańskim ${ }^{1}$. W pierwszych wiekach pięćdziesiąt dni od misterium zmartwychwstania do zstąpienia Ducha przeżywane było jak jeden dzień w Duchu Świętym - „W tajemnicy paschalnej widziano wszystko: zmartwychwstanie, uwielbienie (wniebowstąpienie), życie dziecka Bożego udzielone przez Pana zsyłającego swego Ducha"2. Apostołowie co roku starali się przybyć tego dnia do Jerozolimy i wspólnie celebrować rocznicę zstąpienia na nich Świętego Ducha. W Konstytucjach Apostolskich czytamy - „Dziesiątego dnia po Wniebowstąpieniu, to znaczy pięćdziesiątego dnia od pierwszego dnia Pańskiego, macie świętować wielką uroczystość; tego dnia o godzinie trzeciej Pan Jezus zesłał na nas dar Ducha Świętego"’. Jednym z głównych tekstów świadczących o świętowaniu Pięćdziesiątnicy jest fragment jednego z dzieł św. Ireneusza $z$ Lyonu4. Wspomina on o celebrowaniu święta i zakazie zanoszenia modlitw w pozycji klęczącej (podobnie jak

\footnotetext{
М. Скабалланович, Толковый Типикон, Moskwa, 2008, s. 263.

2 Y. Congar, Wierzę w Ducha Świętego. Duch Święty w ,ekonomii”. Objawienie i doświadczenie Ducha. Tom I., przeł. Lucyna Rutowska, Warszawa, 1995, s. 87

3 Konstytucje Apostolskie V: 20,4, w: Konstytucje apostolskie oraz Kanony Pamfilosa z apostolskiego synodu w Antiochii, Prawo kanoniczne świętych Apostołów, Kary świętych Apostołów dla upadlych, Euchologion Serapiona, przeł. Stanisław Kalinkowski, Kraków, 2007, s. 132.

4 М. Скабалланович, Толковыц̌..., dz. cyt., s. 68.
}

w Niedzielę Paschy). O randze święta świadczy również fakt, iż Pięćdziesiątnica była jednym z trzech dni w roku, w których patriarcha Konstantynopola nakładał sakkos ${ }^{5}$ - szatę koronacyjną podarowaną przez cesarza bizantyjskiego $^{6}$. W tym dniu dokonywano później również chrztu katechumenów, stąd na Liturgii zamiast trisagionu ${ }^{7}$ śpiewa się pieśn „Którzy w Chrystusie ochrzczeni są, w Chrystusa przyobleczeni są" (podobnie jak w Boże Narodzenie, Epifanię, Sobotę Łazarza, Wielką Sobotę i w Tygodniu Paschalnym).

Tradycja świętowania Pięćdziesiątnicy sięga judaizmu. To jedno $\mathrm{z}$ trzech najważniejszych świąt $\mathrm{w}$ roku (obok Paschy i Święta Namiotów). Znane jest ono pod wieloma nazwami, m.in. Pięćdziesiątnica (hebr. Szawuot), Święto Tygodni, Dzień Pierwocin, Święto Żniw, Świąteczne Zgromadzenie ${ }^{8}$. Tego dnia wspomina się nadanie Prawa na Górze Synaj (nastąpiło ono po pięćdziesięciu dniach od wyjścia z Egiptu) i tułaczkę Izraelitów po pustyni w drodze do Ziemi Obiecanej9. W Pięćdziesiątnicę do Jerozolimy przybywało mnóstwo pielgrzymów - Żydów mieszkają-

\footnotetext{
Ks. H. Paprocki, Misterium Eucharystii, Kraków, 2010, s. 144.

6 Sakkos jest obecnie jedną z szat liturgicznych każdego biskupa.

Trisagion - aklamacja „Święty Boże, Święty Mocny, Święty Nieśmiertelny, zmiłuj się nad nami” śpiewana podczas Liturgii katechumenów przed lekturą Pisma Świętego.

8 Szawuot, w: Internetowa Encyklopedia PWN, http://encyklopedia. pwn.pl/haslo/3982604/szawuot.html [dostęp: 13.08.2012 r.]

9 Synaksarion Niedzieli Świętej Pięćdziesiątnicy [przeł. ks. Henryk Paprocki], http://www.liturgia.cerkiew.pl/pages/File/docs/on-37-piecdziesiatnica.pdf [dostęp: 20.09.2012 r.]
} 
cych w diasporze, którzy przyjechali na ojczyste ziemie ${ }^{10}$. Świadectwem tego była m.in. duża obecność cudzoziemców w dniu zesłania Św. Ducha na Apostołów. W Dziejach Apostolskich czytamy - „Przebywali wtedy w Jeruzalem pobożni Żydzi ze wszystkich narodów pod słońcem (...) Partowie i Medowie, i Elamici, i mieszkańcy Mezopotamii, Judei oraz Kapadocji, Pontu i Azji, Frygii oraz Pamfilii, Egiptu i tych części Libii, które leżą blisko Cyreny, i przybysze z Rzymu, Żydzi oraz prozelici, Kreteńczycy i Arabowie" (Dz 2,5-10).

Obchody święta Pięćdziesiątnicy trwają (podobnie jak W przypadku tygodnia paschalnego) siedem dni. W tym okresie całkowicie zniesiony jest post ${ }^{11}$. Niedziela następująca po Zesłaniu Św. Ducha na Apostołów poświęcona jest pamięci wszystkich świętych. To ostatni dzień lektury księgi liturgicznej o nazwie triodion paschalny (Pentekostarion).

Nabożeństwa Pięćdziesiątnicy nie różnią się strukturalnie od nabożeństw innych świąt. W ich skład wchodzą: mała wieczernia, wielka wieczernia, jutrznia, godziny kanoniczne (wielka wieczernia, jutrznia i pierwsza godzina tworzą w tradycji słowiańskiej jedno wspólne nabożeństwo całonocnego czuwania), Święta Liturgia (będąca centralnym nabożeństwem święta). W praktyce parafialnej zwykle zaraz po Liturgii odprawiana jest wieczernia (rozpoczynająca już Poniedziałek Świętego Ducha), na których prezbiter czyta siedem modlitw autorstwa św. Bazylego Wielkiego. Podczas ich lektury wierni po raz pierwszy od Wielkiej Środy klęczą. Według tradycji na nabożeństwa Tygodnia Pięćdziesiątnicy duchowni przyodziewają zielone szaty liturgiczne. Świątynia często zdobiona jest kwiatami i gałązkami drzew. Symbolizuje wpływ Ducha Świętego na naturę - życiodajną moc, dzięki której przyroda co roku odradza się na nowo.

Świąteczne nabożeństwo Pięćdziesiątnicy rozpoczyna uroczyście wielka wieczernia ze swoją bogatą hymnografią. Przed rozpoczęciem analizy hymnów tegoż nabożeństwa należałoby dokładnie określić ich liczbę i strukturę (uwzględniając fakt, że wiele $\mathrm{z}$ nich powtarza się w różnych częściach nabożeństwa). W zestawieniu pominięta została mała wieczernia, co wynika z faktu, że wszystkie teksty z małej wieczerni pojawiają się także na wielkiej. Struktura analizowanej hymnografii przedstawia się w sposób następujący:

\begin{tabular}{|c|c|l|c|}
\hline $\begin{array}{c}\text { Nazwa } \\
\text { hymnu } \\
\text { lub grupy } \\
\text { hymnów }\end{array}$ & Ton $^{1}$ & \multicolumn{1}{|c|}{ Autor } & $\begin{array}{c}\text { Liczba } \\
\text { hymnów }\end{array}$ \\
\hline \multirow{2}{\text{Stichery}}{$\begin{array}{c}\text { na „Panie, } \\
\text { wołam” } \\
\text { (cs. Hospodi } \\
\text { wozzwach) }\end{array}$} & 1. & $\begin{array}{l}\text { Brak informacji; } \\
\text { inspiracje z twórczości } \\
\text { św. Grzegorza Teologa }\end{array}$ & 3 \\
\cline { 2 - 4 } & 8. (4. plagialny) & $\begin{array}{l}\text { Brak informacji } \\
\text { Cesarz Leon VI }\end{array}$ & 5 \\
\hline Filozof (IX-X w.) & 1 \\
\hline
\end{tabular}

\footnotetext{
10 Вениамин, епископ Владивостокский и Приморский, Священная Библейская История Нового Завета, Poczajów, 2005, s. 130.

${ }_{11}$ Zob. B. Bobrinskoy, Życie liturgiczne, przeł. Janina Dembska, Warszawa, 2004, s. 125.
}

\begin{tabular}{|c|c|c|c|}
\hline \multirow[t]{2}{*}{$\begin{array}{l}\text { Stichery } \\
\text { na litii }\end{array}$} & $\begin{array}{l}\text { 2. / powtórzenie } \\
\text { trzech sticher z } \\
\text { „Panie wołam” }\end{array}$ & Brak informacji & 3 \\
\hline & 8. (4. plagialny) & Brak informacji & 1 \\
\hline \multirow{2}{*}{$\begin{array}{l}\text { Stichery na } \\
\text { stichownie }\end{array}$} & 6. (2. plagialny) & $\begin{array}{l}\text { Św. Kosma z Majumy } \\
\text { (VIII w.) }\end{array}$ & 3 \\
\hline & 8. (4. plagialny) & Brak informacji & 1 \\
\hline Troparion & 8. (4. plagialny) & Brak informacji & 1 \\
\hline $\begin{array}{l}{ }^{1} \text { Podano num } \\
\text { racja według tı } \\
\text { Собрание тво } \\
\text { pa, 1994, s. } 57\end{array}$ & ę tonów wedh & $\begin{array}{l}\text { dycji słowiańskiej, w n } \\
\text { Zob. Святитель Григо } \\
\text { 1., Свято-Троицкая С }\end{array}$ & \\
\hline
\end{tabular}

\section{Stichery na „Panie, wołam”}

Stichery na „Panie, wołam” można podzielić na trzy grupy zarówno według tonów melodycznych jak i treści. Pierwszą grupę stanowią trzy pierwsze stichery opisujące powszechne znaczenie Zesłania Świętego Ducha. Kolejna grupa to pięć sticher opowiadających o znaczeniu Pięćdziesiątnicy dla nas. Ostatnia stichera śpiewana podczas wieczornego wejścia z kadzidłem stanowi odrębny znamienity tekst. Podział sticher na opisujące wydarzenie od strony obiektywnej i subiektywnej proponuje także rosyjski liturgista M. Skabałłanowicz ${ }^{12}$.

Pierwsza ze sticher stanowi wprowadzenie do całości hymnów opiewających Zesłanie Świętego Ducha na apo-

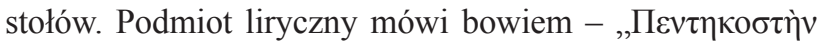

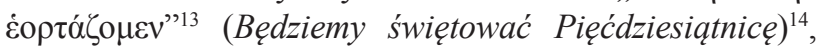
a następnie wymienia czym Pięćdziesiątnica jest dla Ko-

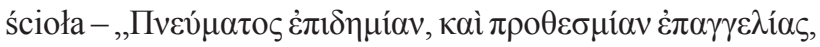

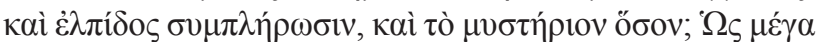

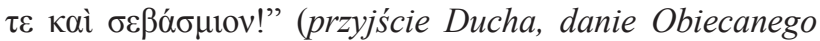
[spetnienie obietnicy - przyp. aut.], wypetnienie nadziei, tak samo zaś tajemnicze, jak wielkie i czcigodne). Hymn kończy apostrofa teocentryczna „,

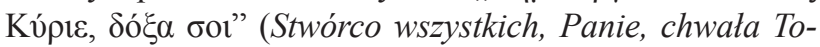
bie). Tekst stichery, z wyjątkiem epilogu, jest fragmentem homilii pentekostalnej św. Grzegorza Teologa ${ }^{15}$.

Druga stichera opowiada o jednym z celów Pięćdzie-

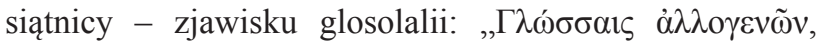

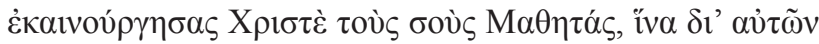

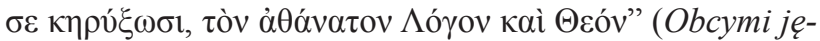
zykami odnowiteś, Chryste, Twoich uczniów, aby w nich glosili Ciebie, Nieśmiertelne Stowo i Boga). Apostołowie otrzymali dar głoszenia Chrystusa w różnych językach, których dotąd nie znali. Motyw języków występuje w wie-

М. Скабалланович, Христианские праздники. Пятидесятнииа, Kijów, 1916, s. 58

13 Cytaty tekstów liturgicznym w języku starogreckim, za:

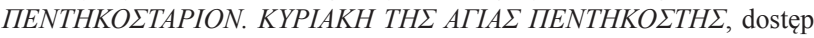
on-line: http://www.christopherklitou.com/pentecostarion_sunday_of_ pentecost_greek.htm

14 Cytaty tekstów liturgicznych w thumaczeniu na język polski, za: NIEDZIELA ŚWIĘTEJ PIĘĆDZIESIĄTNICY, thum. Ks. Henryk Paprocki, dostęp on-line: http://www.liturgia.cerkiew.pl/pages/File/docs/festum25-zeslanie.pdf

15 zob. Святитель Григорий Богослов, Собрание..., dz. cyt., s. 578. 
lu hymnach w różnych kontekstach. Bardzo często napotykamy na zestawienie języków ognia z darem języków. Temat ten zostanie podjęty także w kolejnych hymnach pojawią się liczne metafory i porównania.

Trzecia ze sticher poświęcona jest Świętemu Duchowi. Rozpoczyna ją proste acz niezwykle treściwe stwierdzenie

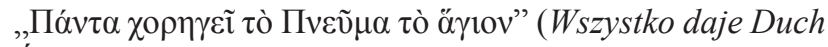
Święty). Rzeczywiście, to On jest Dawcą wszelkich dóbr i, według Ojców Kościoła, zawsze obecny był w ekonomii Bożej ${ }^{16}$. Św. Bazyli Wielki pisze - „Przyjście Chrystusa Duch go poprzedza. Wcielenie - Duch jest. Cudowne działania, łaski i uzdrowienia - przez Ducha Świętego. Wypędzone demony - przez Ducha Bożego. Diabeł zniewolony - w obecności Ducha. Odpuszczenie grzechów - w łasce Ducha Świętego..." ${ }^{\prime 1}$.

Za pierwszymi słowami trzeciej stichery następuje lista przykładów świadczących o prawdziwości wypowiedzi

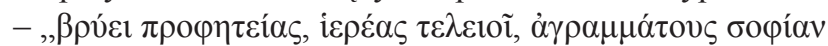

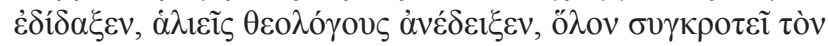

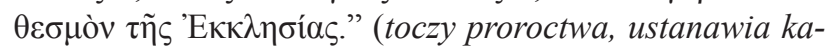
płanów, madrości nauczyt nieuczonych, rybaków okazat teologami, zbiera cate zgromadzenie Kościoła).

Rzeczywiście, trzecia hipostaza Trójcy Świętej czyni niektórych ludzi zdolnymi prorokowania ${ }^{18}$ oraz mówi przez proroków. Takie stwierdzenie znajdujemy m.in. w VIII artykule Niceo-Konstantynopolitańskiego Wyznania Wiary - „I w Ducha Świętego (...) który mówił przez proroków"19. Duch Święty ustanawia także kapłanów. Warto zwrócić uwagę na grecki czasownik użyty w ory-

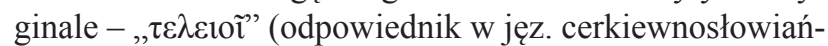
skim: „,совершает”). Ma on wielorakie i głębokie w tym kontekście znaczenie - „dokonywać, wypełniać, czynić doskonałym, wtajemniczać, uświęcać”20. Duch Święty zatem nie tylko ustanawia kapłanów, ale sprawia również, że

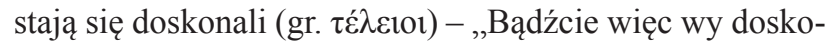
nali, jak doskonały jest Ojciec wasz niebieski” (Mt 5,48). Takie rozumienie kontekstu słów proponuje angielskie thumaczenie Kościoła Prawosławnego w Ameryce (OCA) - „He leads priests to perfection”21, o ile np. współczesny francuski przekład proponuje termin „ustanawia” - „Il institue les prêtres"22.

Według podmiotu lirycznego Duch Święty uczy mądrości nieuczonych i rybaków okazuje teologami. Na kanwie tego kontrastu zbudowanych jest jeszcze kilka innych hymnów.

Trzecia osoba Trójcy Świętej zbiera również zgromadzenie Kościoła - wzywa do jedności i jest tej jedności

\footnotetext{
16 por. И. Попович, Догматика Православной Церкви. Пневматология, Moskwa, 2007, s. 6.

17 Bazyli Wielki, O Duchu Świętym, przeł. Alina Brzóstkowska, Warszawa, 1999, s. 135

18 zob. И. Попович, Догматика..., dz. cyt., s. 60.

19 Katechizm, Warszawa, 1938, s. 24.

20 R. Popowski SDB, Grecko-polski słownik syntagmatyczny Nowego Testamentu, Warszawa, 2008, s. 1084.

${ }^{21}$ May 27: Holy Pentecost, dostęp on-line: https://oca.org/liturgics/service-texts

22 OFFICE DE LA PENTECÔTE, dostęp on-line: http://orthodoxie.typepad.com/ficher/pentecote_slfr.pdf
}

gwarantem. Wyraźnie pisze o tym serbski teolog Justyn Popović - „Jedność chrześcijan buduje i daje Duch Święty (...) Poza Świętą Trójcą - Boską Jednością - człowiek cały jest rozproszony, rozbity, podzielony na atomy, molekuły, zdezintegrowany i w żaden sposób nie może się zebrać, a w każdej części jego rozbitej przez grzech i rozdwojonej duszy trwają niezliczone męki”’23. Jednym z przejawów jednoczącej mocy Ducha jest glosolalia - „Duch Święty głosi jedną Ewangelię zbawienie w różnych językach i w ten sposób łączy wszystkich ludzi i wszystkie narody w Panu Chrystusie i Jego Ewangelii"'24.

Życie Kościoła przepełnione jest Duchem Świętym. Każdy członek Kościoła przystępujący do sakramentów jest uczestnikiem łaski trzeciej hipostazy Trójcy. Nie bez powodu apostoł Paweł kończy jeden ze swoich listów pozdrowieniem - „Łaska Pana Jezusa Chrystusa, miłość Boga i dar jedności w Duchu Świętym niech będą z wami wszystkimi”25 (2 Kor 13,14). Ów „dar jedności w Duchu

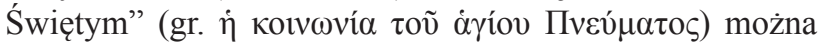
thumaczyć również jako wspólnotę i uczestnictwo w Duchu Świętym.

Dar Pięćdziesiątnicy posiada kilka wymiarów. Biskup Kallistos (Ware) rozróżnia trzy: dar dla wszystkich ludzi (charyzmatykami są wszystkie ochrzczone osoby), dar jedności (zjednoczenie zgromadzenia w jedno mistyczne Ciało Chrystusa oraz jednomyślność, jednogłośność) i dar różnorodności (każdy człowiek jest nosicielem innej osobowości) ${ }^{26}$.

Duch Święty przedstawiony jest zatem jako Ten, który wzbogaca różnorodnością, ale jednocześnie Ten, który jednoczy. Tworzy więc jedność w wielości ${ }^{27}$. To dzięki Duchowi Świętemu wielość i różnorodność przestają być przyczyną podziału. Jedność możliwa jest bowiem tylko W różnorodności ${ }^{28}$. W tym też wyraża się duża różnica w dziele Syna Bożego i Ducha Świętego. Dzieło Chrystusa odnosi się do natury ludzkiej, którą rekapituluje on w swojej hipostazie. Dzieło Ducha Świętego - przeciwnie - odnosi się do osób, adresowane jest do każdej z nich ${ }^{29}$. Podczas gdy natura ludzka jest odnowiona w sposób jednolity, dary rozdzielone są rozmaicie, z uwzględnieniem różnic i odmienności ${ }^{30}$.

W kolejnej części trzeciej stichery odnajdujemy określenie relacji Ducha Świętego z dwiema pozostałymi hi-

\footnotetext{
23 И. Попович, Догматика..., dz. cyt., s. 99.

24 Tamże, s. 60.

25 Pozdrowienie apostolskie zostało także włączone do Liturgii - celebrans pozdrawia tymi słowami wiernych podczas Liturgii św. Jana Chryzostoma i św. Bazylego Wielkiego na początku anafory, zob. Boska Liturgia Świętego Ojca naszego Jana Chryzostoma, Warszawa, 2001, s. 76. 26 K. Ware, Prawostawna droga, przeł. s. Nikolaia, Białystok, 1999, s. 101 .

27 zob. K.Ch. Felmy, Współczesna teologia prawosławna, przeł. ks. Henryk Paprocki, Białystok, 2005, s. 140.

28 W. Hryniewicz OMI, Dar Zmartwychwstałego. Pneumatologia prawosławna i jej znaczenie dla ekumenii, w: Duch, który jednoczy. Zarys pneumatologii, red. M. Marczewski, Lublin, 1998, s. 216.

29 por. M. Łosski, Teologia mistyczna Kościoła Wschodniego, przeł. Maria Sczaniecka, Warszawa, 1989, s. 148

30 M. el-Maskîne, Modlitwa, Duch Święty i jedność chrześcijan, przeł. Agnieszka Małecka-Petit, Kraków, 2005, s. 76.
} 


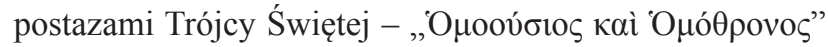
(Wspótistotny $i$ Wspóttronujacy). Wszystkie trzy osoby są tej samej istoty oraz są współtronujące, współpanujące, współkrólujące. Za pomocą pierwszego terminu została zdogmatyzowana relacja Ojca i Syna podczas I Soboru Powszechnego w 325 r. Drugi termin przeniknął do teologii z mitologii greckiej. Współtronowaniem określano relacje mitycznych bogów Zeusa i Hery ${ }^{31}$.

Hymn kończy apostrofa do Ducha Świętego -

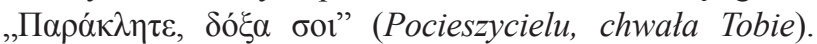
Określenie „Paraklet” jest często obecne w hymnografii. W odniesieniu do Świętego Ducha termin „Paraklet” pojawia się po raz pierwszy w Ewangelii św. Jana. Określenie to odnosi się do Świętego Ducha nie przez pryzmat natury, ale funkcji, jaką pełni. Słowo pochodzi od strony biernej czasownika „, $\pi \alpha \alpha \kappa \alpha \lambda \varepsilon \dot{\varepsilon} \omega ”$ (przywoływać) i oznacza w literaturze greckiej osobę przywołaną, rzecznika, obrońcę, asystenta, doradcę, pośrednika ${ }^{32}$. Pojęcie to używane jest w sądownictwie i oznacza osobę wezwaną na pomoc, która przemawia w imieniu oskarżonego. Obecnie częściej używanym określeniem jest łaciński odpowiednik ,parakleta” o identycznej etymologii - „adwokat”. Grecki „paraklet” ma również znaczenie opiekuna nieletnich i pocieszyciela, stąd też „ostatni odcień znaczeniowy utrwalił się w polskich przekładach biblijnych od wieku XVI po dziś dzien'"33.

Tak jak Parakletem względem Syna jest Duch $^{34}$, Parakletem względem Ojca jest Jezus Chrystus ${ }^{35}$, który pełni rolę naszego orędownika, rzecznika przed Bogiem Ojcem - „Jeśliby nawet kto zgrzeszył, mamy Rzecznika wobec Ojca - Jezusa Chrystusa sprawiedliwego" ${ }^{\text {36 }}(1 \mathrm{~J} 2,1)$. Funkcja Parakleta w przypadku Świętego Ducha odwołuje się do odkrywania przezeń Chrystusa i aktualizowania Jego przyjścia na ziemię. Przyjście Świętego Ducha jest bowiem związane z odejściem Chrystusa. Mówi o tym sam Zbawiciel - „Pożyteczne jest dla was moje odejście. Bo jeżeli nie odejdę, Pocieszyciel nie przyjdzie do was. A jeżeli odejdę, poślę Go do was" (J 16,7). To nowy etap w historii obecności Boga pośród ludzkości. Będąc „innym” niż Chrystus, Duch Święty pomaga odczuć pełnię przyjścia Chrystusa.

W tekstologii Pięćdziesiątnicy temat Parakleta podejmowany jest zwykle w opisach relacji pomiędzy hipostazami Trójcy Świętej. Parakletem nazwie Ducha cesarz

\footnotetext{
М. Скабалланович, Толковый..., dz. cyt., s. 60

Por. Y. Congar, Wierze..., dz. cyt., s. 97

O. A. Jankowski OSB, Zarys pneumatologii Nowego Testamentu, Kraków, 1982, s. 38

34 Z relacji Boga Syna i Ducha Świętego wynika określanie przez Ojców Syna „wielkim Prekursorem Ducha Świętego”, zob. P. Evdokimov, Duch Święty w tradycji prawosławnej, przeł. Maria Żurowska Poznań, 2012, s. 128 .

35 Параклет, w: Словарь Библейского Богословия http://krotov.info/ spravki/essays bible/comments/15p.htm\#p3 [dostęp: 26.07 .2012 r.];

36 Tłumaczenie terminu „Paraklet” jako „Rzecznik” pojawia się m.in. w Biblii Jakuba Wujka (zob. Biblia to jest ksiegi Starego $i$ Nowego Testamentu, Lublin, 1985 ), Biblii Tysiąclecia (zob. Pismo Święte Nowego Testamentu i Psalmów w przekładzie z języków oryginalnych, Warszawa, 1976), zaś jako „Orędownik” m.in. w Edycji Świętego Pawła (zob. Pismo Święte Nowego Testamentu i Psalmy. Najnowszy przekład z języków oryginalnych z komentarzem, Częstochowa, 2005), Przekładzie Ekumenicznym (zob. Listy św. Jana. Przekład ekumeniczny, Warszawa, 1996).
}

Leon w ostatniej sticherze na „Panie, wołam”. W czwartej pieśni kanonu z powieczerza podejmowany jest temat zesłania Świętego Ducha w kontekście wypełnienia obietnicy i ukazania relacji z Ducha z Ojcem i Synem. Francuski przekład tekstów Pięćdziesiątnicy używa zarówno greckiego terminu „Paraclet” jak i francuskiego thumaczenia „Consolateur”. O ile „Pocieszyciel” z trzeciej stichery to „Paraclet”, o tyle „Pocieszający Duch” (

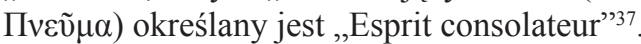

Dwa razy w tekstologii Pięćdziesiątnicy (w ikosie i kanonie powieczerza) występuje rzeczownik odczasownikowy określający nie osobę, lecz czynność - „pocieszenie". W dziewiątej pieśni kanonu Teofanesa czytamy wezwanie - „Przyjdź do nas, Pocieszycielu, napełniając Twoim pocieszeniem, błogosławiąc niewypowiedzianą chwałą Twoją" ${ }^{38}$. W greckim oryginale rzeczownik ów brzmi: „, $\alpha \rho \alpha \mu v \theta i ́ \alpha v ”$ i oznacza dosłownie ,dodanie otuchy, pocieszenie”. Mimo niemal identycznego wydźwięku terminu „Pocieszyciel” i ,pocieszenie” w thumaczeniach cerkiewnosłowiańskim i polskim, terminy te mają odmienną etymologię.

Czwarta stichera opisuje znaczenie Ducha Święte-

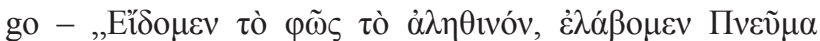

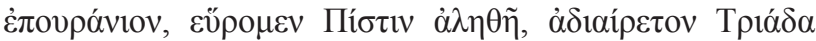

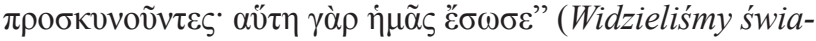
ttość prawdziwa, przyjęliśmy Ducha z Niebios, znaleźliśmy wiare prawdziwa, niepodzielnej Trójcy kłaniamy się, albowiem Ona nas zbawita). Utwór ten, poza faktem, iż jest częścią hymnografii święta Pięćdziesiątnicy, jest śpiewany na koniec każdej Świętej Liturgii - po przyjęciu Eucharystii ${ }^{39}$. Wyraża on psychosomatyczną radość wiernych następującą po przyjęciu Sakramentu, a także zapewnia o braku wszelkich wątpliwości, co do słuszności wiary. Tekst hymnu ukazuje, że Duch Święty „ustanawia i przypieczętowuje komunię w Synu, wszystkich nas czyni członkami Chrystusa, współdziedzicami” ${ }^{\prime 0}$. Równocześnie przyjęcie Ciała i Krwi Chrystusa jest uczestnictwem we wspólnocie Ducha Świętego (komunia staje się komunią Ducha Świętego) ${ }^{41}$. „Doświadczenie Ducha Świętego jest nade wszystko doświadczeniem sakramentalnym" "22. Światłością, o której mowa w utworze, jest Bóg. W dniu Pięćdziesiątnicy był to Duch Święty, który objawił się pod postacią ognistych języków, na każdej Liturgii zaś jest to Chrystus, przyjmowany realnie przez wiernych poprzez Jego Ciało i Krew.

Piąta stichera rozpatruje Pięćdziesiątnicę w kontekście historycznym - w metaforyczny sposób łączy starotestamentowe i nowotestamentowe znaczenie Ducha Świętego

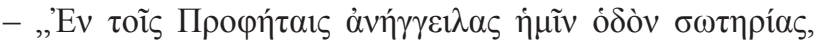

OFFICE DE LA... dz. cyt.

38 NIEDZIELA ŚWIETTEJ..., dz. cyt., s. 25.

39 Z wyjątkiem okresu od Niedzieli Paschy do soboty przed Niedzielą Pięćdziesiątnicy - w tym czasie nie są śpiewane podczas żadnego nabożeństwa stichery: „Królu Niebieski” i analizowana „Widzieliśmy światłość prawdziwą".

40 P. Evdokimov, Duch Świety..., dz. cyt., s. 141.

41 Por. ks. H. Paprocki, Duch Święty w sakramentach Kościoła, w: Duch, który jednoczy..., dz. cyt., s. 298.

42 W. Hryniewicz OMI, Dar Zmartwychwstałego..., w: Duch, który jednoczy..., dz. cyt., s. 218. 


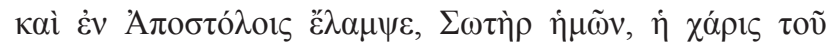

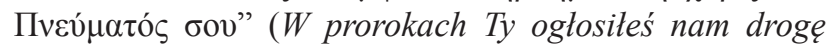
zbawienia $i$ w apostolach zajaśniała, Zbawco nasz, taska Ducha Twego). Duch Święty, jak już zostało wcześniej wspomniane, przemawiał przez proroków. To właśnie w dużej mierze dzięki profetycznym wizjom pneumatoforycznych (cs. духоносных) mężów Lud Wybrany poznawał wolę Bożą. W Nowym Testamencie apostołowie otrzymują Ducha Świętego, który oświeca ich, umacnia, naucza i daje odwagę do głoszenia Słowa Bożego.

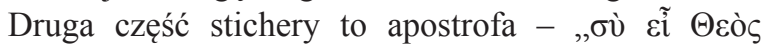
$\pi \rho \tilde{\omega} \tau o \zeta$, ,

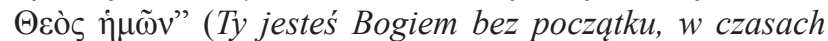
ostatecznych i na wieki Ty jesteś Bogiem naszym). Pierwszą część frazy można przetłumaczyć dosłownie jako: „Ty jesteś Bogiem pierwszym, Ty i po nich (potem)". To cytat z Księgi Izajasza (Iz 44,6) oraz nawiązanie do Apokalipsy św. Jana, w której Bóg mówi - „Jam jest Pierwszy i Ostatni" (Ap 1,17).

Kolejne dwie stichery mają podobną budowę. Odnoszą się do zwyczaju czytania w wieczór Niedzieli Pięćdziesiątnicy specjalnych modlitw św. Bazylego Wielkiego, podczas których wierni - po raz pierwszy od Wielkiego Tygodnia - klęczą. Pierwsza stichera opowiada o modli-

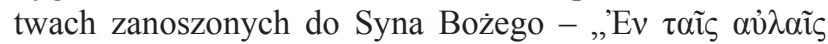

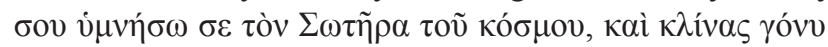

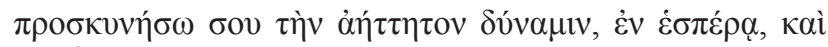

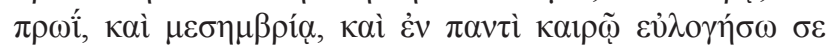
Kúpıє" (Na dziedzińcach Twoich ${ }^{43}$ zaśpiewam Tobie, Zbawco świata, i skloniwszy kolana pokłonię się Twojej niezwyciężonej mocy wieczorem, rano $i w$ potudnie, $i w$ każdym czasie błogostawię Ciebie, Panie). Drugi tekst zapowiada modlitwę na kolanach do wszystkich trzech osób

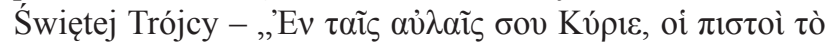

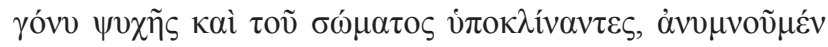

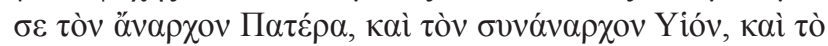

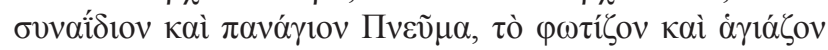

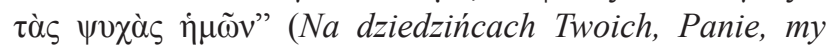
wierni skłoniwszy kolana dusz i ciat, śpiewamy Tobie, Ojcu nie majacemu początku, Synowi wspólnie nie majaсети poczatku $i$ wspótwiecznemu, i Najświętszemu Duchowi, uświęcajacemu i rozjaśniajacemu dusze nasze). W apostrofie kończącej tekst pojawia się rozróżnienie na poszczególne hipostazy. Wobec trzeciej podmiot liryczny używa określenia „, „Wszechświęty Duch”.

Treścią przedostatniej ze sticher na „Panie, wołam” jest bezsporne podporządkowanie nauczaniu Kościoła. W pierwszej części napotykamy parenetyczną frazę

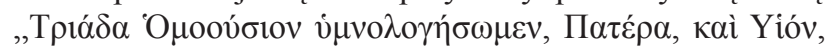

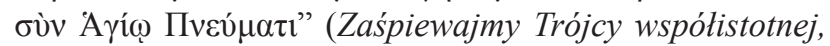
Ojcu i Synowi ze Świętym Duchem), w drugiej zaś pro-

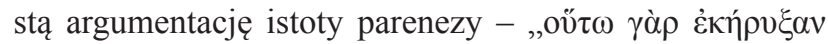

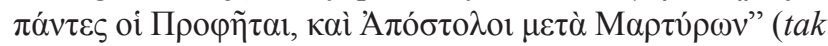
bowiem glosili wszyscy prorocy $i$ apostołowie $z$ męczennikami). Prawdziwy chrześcijanin nie potrzebuje żadnych

\footnotetext{
43 Por. Ps 135(134),2
}

dowodów i thumaczeń, dlaczego jest tak, a nie inaczej. Powinien kroczyć po drodze wyznaczonej przez proroctwa, naukę apostołów i krew męczenników.

Autorstwo ostatniej stichery należy do cesarza Leona VI Filozofa. Hymn jest bogaty pod względem treści jak i estetyki literackiej. To wykładnia prawosławnej teologii Świętej Trójcy. Opisuje relacje między hipostazami Przenajświętszej Trójcy. Utwór można podzielić na kilka części. Pierwszą z nich jest pareneza wzywająca do adoracji

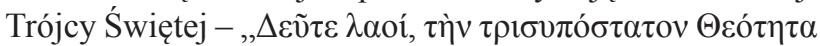

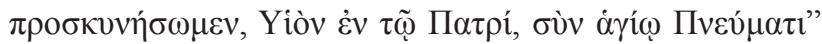
(Przyjdźcie, ludzie, poktońmy się trójhipostatycznemu Bóstwu, Synowi w Ojcu ze Świętym Duchem). W drugiej części poematu podmiot liryczny podkreśla jedność i wspólistot-

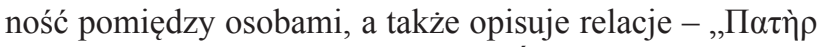

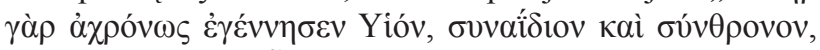

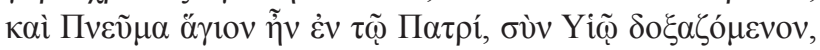

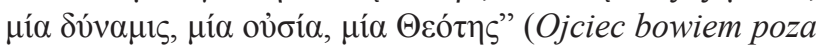
czasem zrodzit Syna wspótistotnego $i$ wspóttronujacego, $i$ Duch Święty byt w Ojcu wystawiany z Synem, jedna moc, jedna natura, jedno Bóstwo).

W trzeciej części poematu ujawnia się podmiot, którym są wszyscy wierni. Inaczej wygląda sytuacja z adresatem. Zauważamy tu pewną konwersję, w efekcie której adresatami nie są ludzie, ale poszczególne hipostazy Trójcy Świętej. Podmiot zwraca się do nich używając słów trisagionu - „Święty Boże” do Boga Ojca, „Święty Mocny” do Boga Syna, „Święty Nieśmiertelny” do Boga Ducha Świę-

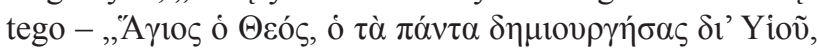

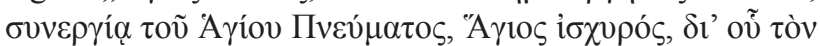

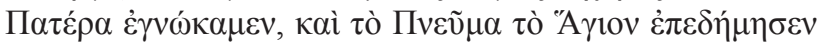

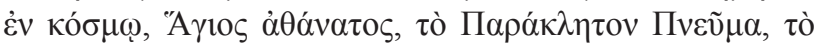

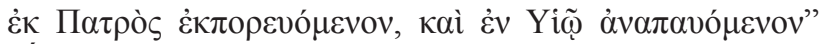
(Święty Boże, który wszystko stworzyleś przez Syna Twego przy wspótudziale Świętego Ducha, Święty Mocny, przez którego poznaliśmy Ojca i Duch Święty przyszedt na świat, Święty Nieśmiertelny, Pocieszycielu, Duchu pochodzacy od Ojca i spoczywajacy w Synu). W hymnie opisywane są relacje między każdą z hipostaz. Bóg Ojciec jest Tym, który tworzy świat przez Syna, dzięki ożywiającej mocy

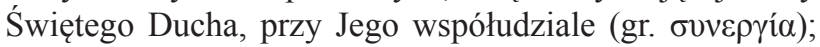
Bóg Syn - Tym, przez którego wszyscy poznali Ojca i na świat przyszedł Duch Święty ${ }^{44}$. Trzecia z hipostaz określana jest jako pochodząca od Ojca i spoczywająca w Synu. Poemat Leona kończy doksologiczna apostrofa ku czci

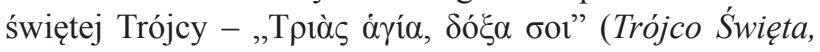
chwała Tobie).

\section{Stichery na litii}

$\mathrm{Na}$ litii występują cztery stichery. Trzy z nich to powtórzenie ciągu sticher z „Panie, wołam”. Wynika to z faktu, że litija jest stosunkowo późną częścią całonocnego

\footnotetext{
44 Zstąpienie i cała działalność Ducha Świętego w bogoludzkim ciele Kościoła dokonuje się dzięki Bogoczłowiekowi i ze względu na Bogoczłowieka, zob. И. Попович, Догматика..., dz. cyt., s. 5.
} 
czuwania i w okresie działalności hymnografów opiewających święto Pięćdziesiątnicy, jeszcze nie występowała ${ }^{45}$. Jedyną oryginalną sticherą na litii jest ta śpiewana jako ostatnia (na „Chwała, i teraz”).

Pierwsza część hymnu opowiada o momencie ze-

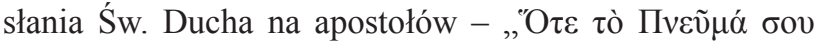

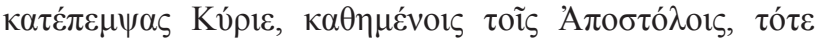

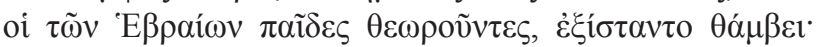

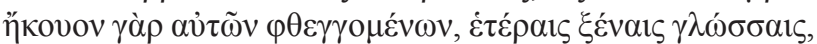

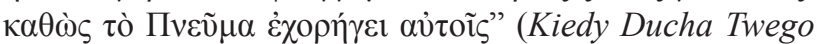
postateś, Panie, na siedzacych apostotów, wtedy dzieci hebrajskie widzac to przerazity sie bardzo, albowiem styszeli ich mówiacymi innymi, obcymi jęzkami, jak dawat im Duch Święty). W drugiej części utworu czytamy o wpływie mocy Ducha na apostołów. Autor tekstu zwraca uwagę na fakt, iż niewykształceni prości ludzie stali się teologami,

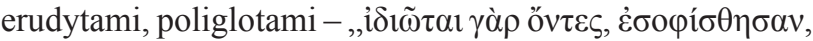

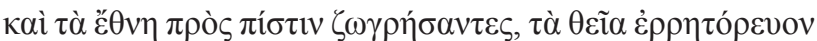
(będac bowiem niewyksztatconymi oni stali się madrymi i przemawiali o sprawach Bozych, towiac narody do wiary). Epilogiem tekstu jest apostrofa do Chrystusa - „ó غ̇ंì

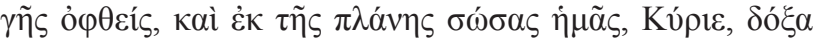
бoı" (Ty, który zjawiteś się na ziemi $i$ wybawiteś nad od pobtadzenia, Panie, chwała Tobie).

\section{Stichery na stichownie}

Kolejną grupę wśród hymnów liturgicznych z wieczerni stanowią tzw. stichery na stichownie (apostychesy). Autorstwo trzech z nich bezsprzecznie należy do św. Kosmy z Majumy.

W dwóch pierwszych sticherach użyty jest kontrast. Autor dzieli ludzi na dwie grupy - pogan nierozumiejących mocy Świętego Ducha i chrześcijan, dla których Duch Święty jest umocnieniem i jedną z podstaw wiary. Pierwszą grupę autor opisuje w trzeciej osobie, drugą zaś w pierwszej, przez co uczestnikami wiary czyni wszystkich

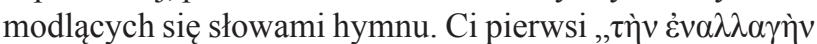

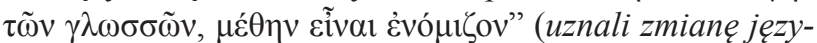

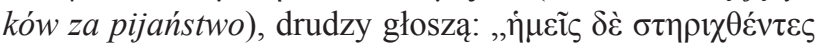

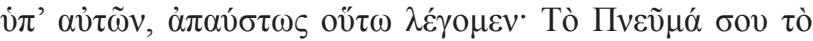

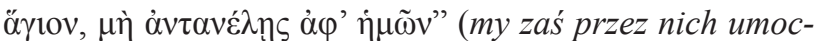
nieni, nieustannie tak mówimy: Ducha Twego Świętego nie zabieraj od nas). Podobny motyw znajdujemy w dru-

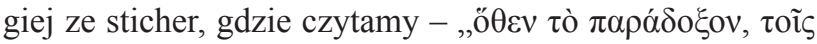

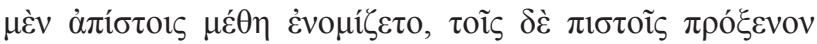

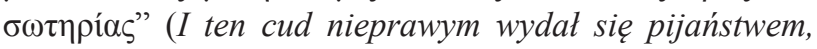
a dla wiernych orędownikiem zbawienia). Epilog pierwszego z apostychów pochodzi z 50. psalmu ${ }^{46}$.

Trzecia ze sticher jest niezwykle ważnym hymnem ze względu na częstotliwość użycia podczas wszystkich nabożeństw. Stichera św. Kosmy „Królu Niebieski” (cs. Царю Небесный) jest z pewnością najbardziej znanym i najczęściej używanym hymnem ze zbioru wszystkich tek-

\footnotetext{
45 М. Скабалланович, Толковый..., dz. cyt., s. 69.

46 Ps 51(50), 13 .
}

stów Pięćdziesiątnicy. Modlitwą tą rozpoczynają się niemalże wszystkie nabożeństwa. Recytuje ją również kapłan tuż przed rozpoczęciem Świętej Liturgii. Hymnu tego nie używa się jednak od Paschy do Pięćdziesiątnicy. W okresie paschalnym zastępuje ją troparion Paschy. Związane jest to z celebrowanym liturgicznie okresem, którego cechami są m.in. niezwykła radość i oczekiwanie na nieobecnego jeszcze Ducha Świętego. W tym wyjątkowym okresie hymny paschalne zastępują wiele stałych elementów nabożeństw. Obecność Chrystusa zmartwychwstałego jest tak realna, przeżywana $\mathrm{z}$ taką intensywnością, że wiele hymnów zostaje zastapionych troparionem wielkanocnym ${ }^{47}$. Przez kolejne dni - święto Wniebowstąpienia, następującą po nim oktawę i sobotę dusz - wierni są niczym apostołowie oczekujący wypełnienia obietnicy zesłania Pocieszyciela. Momentem, w którym hymn „Królu Niebieski” rozbrzmiewa po raz pierwszy od Wielkiej Soboty są stichery na stichownie w trakcie wieczerni Pięćdziesiątnicy.

Stichera „Królu Niebieski” składa się z dwóch części. Pierwsza $\mathrm{z}$ nich to apostrofa zawierająca różne pery-

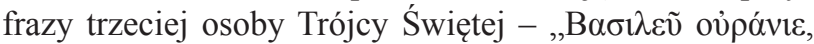

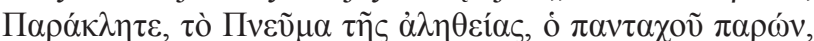

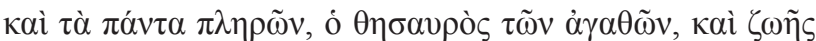

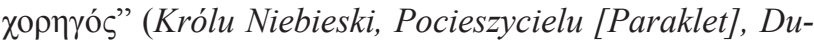
chu Prawdy, który wszędzie jesteś $i$ wszystko napetniasz, Skarbnico dóbr i Dawco życia).

Duch Święty określany jest Królem Niebios, a także Parakletem (termin omawiany przy okazji sticher na „Panie, wołam". Kolejnym z określeń Ducha Świętego jest termin „Duch Prawdy” wyznaczający zakres działalności trzeciej osoby Trójcy Świętej widoczny w Ewangelii św. Jana - czuwanie nad objawieniem ${ }^{48}$. Paraklet podtrzymuje Kościół w prawdzie ${ }^{49}$ i dzięki Jego działaniu Kościół ma na zawsze zapewnioną trwałość i skuteczność słowa Jezusowego ${ }^{50}$. Zadaniem Ducha Prawdy jest także uczenie ludzi wielbienia w duchu i prawdzie ${ }^{51}$. Duch Święty jest także „Dawcą Życia”. Uśmierca w Kościele wszystko, co grzeszne i złe ${ }^{52}$. Jest źródłem życia - ,jak powietrze, jak światło, jak woda i ciepło. Ten, który jest wszędzie obecny i wszystko napełnia, działa w człowieku i w świecie"s3.

Druga część hymnu to prośby skierowane do Ducha

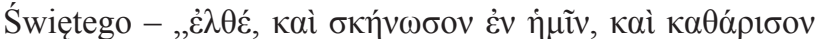

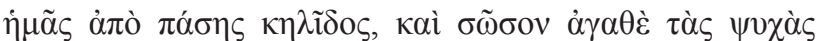
$\eta \dot{\eta} \mu \tilde{\omega} v "$ (przyjdź i zamieszkaj w nas, i oczyść nas od wszelkiej zmazy, i zbaw, o Dobry, dusze nasze).

Podmiot liryczny zwraca się do Ducha Świętego z prośbą: „Przyjdź”. Słowo to można rozpatrywać m.in. w kontekście Modlitwy Pańskiej. Ewagriusz z Pontu uwa-

\footnotetext{
47 Bóg Żywy. Katechizm Kościoła Prawosławnego, przeł. ks. Henryk Paprocki, Kraków, 2001, s. 483.

48 O. A. Jankowski OSB, Zarys... dz. cyt., s. 47.

49 Zob. W. Hryniewicz OMI, Dar Zmartwychwstałego..., w: Duch, który jednoczy..., dz. cyt., s. 218.

50 I. de la Potterie, Le Paraclet, za: o. A. Jankowski OSB, Zarys..., dz. cyt., s. 47.

51 M. el-Maskîne, Modlitwa ..., dz. cyt., s. 80

52 Zob. И. Попович, Догматика..., dz. cyt., s. 19.

53 W. Hryniewicz OMI, Dar Zmartwychwstałego..., w: Duch, który jednoczy..., dz. cyt., s. 220.
} 
ża, że słowa „przyjdź Królestwo Twoje” oznaczają po prostu „Przyjdź Duchu Święty”. Według ascety Królestwo Boże to Duch Święty ${ }^{54}$. Na kanwie wezwania „przyjdź” swój hymn do Ducha Świętego oparł również św. Symeon Nowy Teolog. Pisze: „Przyjdź, światłości prawdziwa. Przyjdź, życie wieczne. Przyjdź, ukryta tajemnico. Przyjdź, bezimienny skarbie. Przyjdź, rzeczywistości nie-

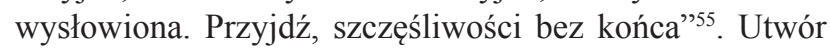
ten ze względu na swoje późne pochodzenie (XI w.) nie wszedł w skład nabożeństwa.

Ostatnia ze sticher zestawia Pięćdziesiątnicę z budową wieży Babel. To nie jedyne miejsce, gdzie pojawia się podobny motyw ${ }^{56}$ - starotestamentowe pomieszanie języków i nowotestamentowy dar mówienia językami, pycha pierwszych konstruktorów i pokora apostołów. Serbski biskup Daniel (Krstić) uważa, że interwencja Boga i pomieszanie języków nie było aktem destrukcyjnym lecz konstrukcyjnym. Był to twórczy akt Boga dający nowe piękno i bogactwo oraz prowadzący do Pięćdziesiątnicy ${ }^{57}$.

Hymn składa się z trzech paralelnie zbudowanych części bazujących na kontraście pomiędzy oboma wyda-

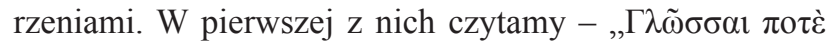

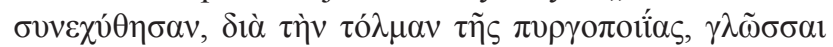

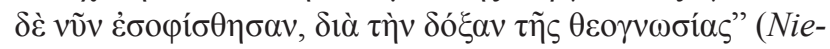
gdyś języki zostały pomieszane z powodu śmiałości budowania wieży, teraz zaś narody obdarzone sa madrościa ze względu na poznanie chwaty Boga). Warto zwrócić uwagę na rzeczownik ,лvрүолойаऽ” (cs. столпотворение) оznaczający tworzenie, budowanie wieży. Pod tym słowem ukryta jest starotestamentowa budowa wieży Babel - poza tym terminem i opisem okoliczności pomieszania języków w hymnie brak jest innego określenia, które mogłoby posłużyć w identyfikacji, chociażby nazwy geograficznej. Od osoby słuchającej czy śpiewającej utwór wymagana jest zatem pewna znajomość Pisma Świętego, bez której trudno zrozumieć wiele tekstów. Zwraca na to uwagę metropolita Hilarion (Alfiejew). Pisze, że dla słuchacza mało obeznanego z biblijną historią i symboliką, teksty liturgiczne są mało zrozumiałe ${ }^{58}$.

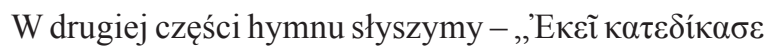

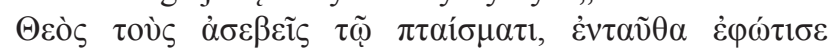

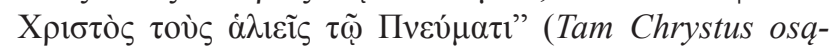
dzit niegodnych za grzechy, tutaj oświecit rybaków Duchem). Nie sposób nie zauważyć paralelnej budowy trze-

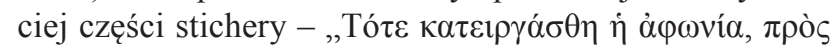

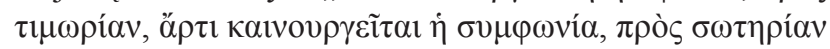

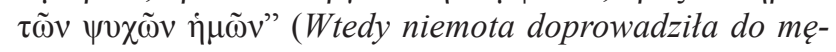
czarni, teraz odnawia się zgoda ku zbawieniu dusz naszych $)^{59}$. Okoliczniki czasu: Tó $\varepsilon \neq \not \alpha \rho \tau$; orzeczenie:

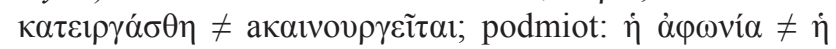

\footnotetext{
54 Tamże, s. 226.

55 Symeon Nowy Teolog, Oratio mystica SCh 156, s. 150-153, za: W. Hryniewicz OMI, Dar Zmartwychwstałego..., w: Duch, który jednoczy..., dz. cyt., s. 229.

56 Innym przykładem jest chociażby kontakion święta na jutrzni.

57 Danilo (Krstić), У почетку беше смисао, Belgrad 1996, s. 185.

58 Hilarion (Alfiejew), ihumen, Misterium wiary, przeł. Jarosław Charkiewicz, Warszawa, 2009, s. 209.

59 Tłum. aut.
}

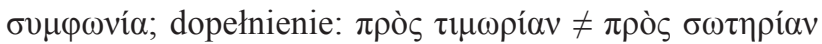

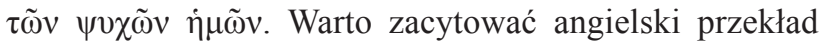
trzeciej części hymnu: „There disharmony was brought about for punishment, now harmony is renewed for the salvation of our souls" $"$.

\section{Troparion}

Kolejnym z hymnów Pięćdziesiątnicy i ostatnim $\mathrm{z}$ wieczerni jest troparion. To najczęściej pojawiający się podczas całego tygodnia świątecznego tekst. Jest on panegiryczną apostrofą skierowaną do drugiej hipostazy Trójcy Świętej. Budowa hymnu jest klamrowa - rozpoczyna

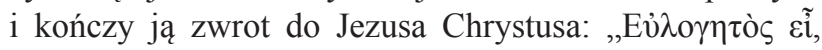
X

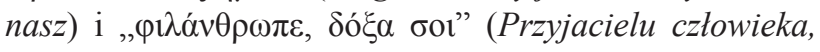
chwata Tobie).

Środkowa część tekstu zawiera motyw kontrastu (nie-

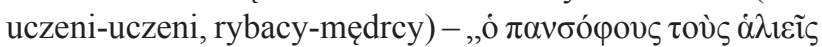

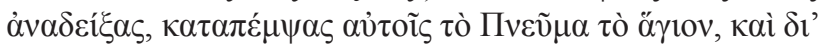

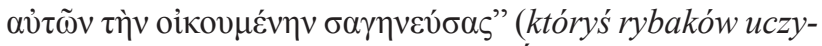
nit mędrcami, zesławszy im Ducha Świętego i przez nich zlowiwszy świat cały). Podkreślana jest tym samym moc Ducha Świętego względem świata - przemienia On ludzi i sprawia, że nieuczeni, niewykształceni, prości ludzie stają się erudytami, poliglotami, mędrcami i teologami. Zrozumieli również cały plan zbawienia. Przedtem, bowiem, nawet po zmartwychwstaniu Chrystusa nie wszystko było dla nich jasne ${ }^{61}$. Postrzeganie apostołów w kolosalny sposób odmieniła właśnie Pięćdziesiątnica.

Działalność Ducha Świętego ma znaczenie uświęcające i odnawiające nie tylko wobec apostołów, ale wobec wszystkich członków społeczności kościelnej. Szczególnym przejawem takich charyzmatyków Ducha Świętego są teoforyczni Ojcowie Kościoła. W hymnografii określani są często jako narzędzia, instrumenty w rękach Ducha Świętego, np. „trąby Ducha Świętego”62, ,najpiękniejsza fletnia Ducha" ${ }^{63}$ w przypadku św. Grzegorza Palamasa i „lira Ducha Świętego” w przypadku św. Efrema Syryjczyka" ${ }^{64}$.

\section{Zakończenie}

Hymnografia Pięćdziesiątnicy jest niewyczerpaną skarbnicą teologii Ducha Świętego i ogólnie Świętej Trójcy. Teksty liturgiczne wieczerni to jedynie składowa część całej tekstologii święta Zesłania Świętego Ducha na Apostołów - wraz z hymnografią jutrzni, znamienitym kano-

\footnotetext{
60 May 27..., dz. cyt.

61 Andrzej Sarwa, Rzeczy ostateczne czlowieka i świata. Eschatologia Kościoła wschodniego, Łódź, 2003.

62 zob. И. Попович, Догматика..., dz. cyt., s. 202.

63 Drugi Tydzień Wielkiego Postu, przeł. ks. Henryk Paprocki, s. 33., http://liturgia.cerkiew.pl/pages/File/docs/n-02-tydzien-paschalny.pdf [dostęp: 13.03.2014 r.]

64 Y. Congar, Wierze..., dz. cyt., s. 127
} 
nem ku czci Św. Ducha z powieczerza i tekstami całego tygodnia świątecznego. Przy poznawaniu omawianych tekstów warto pamiętać jednak nie tylko o znaczeniu lite- rackim, ale także muzycznym i duchowym. Jedynie integralność wspomnianych elementów może zapewnić całościowy oczekiwany odbiór hymnów liturgicznych.

\section{Bibliografia}

Bazyli Wielki, O Duchu Świętym, przeł. Alina Brzóstkowska, Warszawa, 1999.

Вениамин, епископ Владивостокский и Приморский, Священная Библейская История Нового Завета, Poczajów, 2005.

Bobrinskoy Borys, Życie liturgiczne, przeł. Janina Dembska, Warszawa, 2004.

Congar Yves, Wierzę w Ducha Świętego. Duch Święty w ,ekonomii”. Objawienie i doświadczenie Ducha. Tom I., przeł. Lucyna Rutowska, Warszawa, 1995.

Danilo (Krstić), У почетку беше смисао, Belgrad 1996.

Evdokimov P., Duch Święty w tradycji prawosławnej, przeł. Maria Żurowska Poznań, 2012.

Felmy K.Ch., Współczesna teologia prawostawna, przeł. ks. Henryk Paprocki, Białystok, 2005.

Григорий Богослов, Святитель, Собрание творений в 2 томах. Том 1., Свято-Троицкая Сергиевая Лавра, 1994.

Hilarion (Alfiejew), ihumen, Misterium wiary, przeł. Jarosław Charkiewicz, Warszawa, 2009.

Hryniewicz W. OMI, Dar Zmartwychwstatego. Pneumatologia prawosławna i jej znaczenie dla ekumenii, w: Duch, który jednoczy. Zarys pneumatologii, red. M. Marczewski, Lublin, 1998.

Jankowski O. A. OSB, Zarys pneumatologii Nowego Testamentu, Kraków, 1982.

Łosski M., Teologia mistyczna Kościoła Wschodniego, przeł. Maria Sczaniecka, Warszawa, 1989.

M. el-Maskîne, Modlitwa, Duch Święty i jedność chrześcijan, przeł. Agnieszka Małecka-Petit, Kraków, 2005.

Paprocki Henryk., ks., Duch Święty w sakramentach Kościoła, w: Duch, który jednoczy..., dz. cyt.

Paprocki Henryk, ks., Misterium Eucharystii, Kraków, 2010.

Попович И., Догматика Православной Церкви. Пневматология, Moskwa, 2007.

Popowski R. SDB, Grecko-polski słownik syntagmatyczny Nowego Testamentu, Warszawa, 2008.

Sarwa Andrzej, Rzeczy ostateczne czlowieka i świata. Eschatologia Kościoła wschodniego, Łódź, 2003.
Скабалланович М., Толковый Типикон, Moskwa, 2008.

Скабалланович М., Христианские праздники. Пятидесятниųa, Kijów, 1916.

Ware Kallistos, bp, Prawostawna droga, przet. s. Nikolaia, Białystok, 1999.

Boska Liturgia Świętego Ojca naszego Jana Chryzostoma, Warszawa, 2001.

Bóg Żywy. Katechizm Kościoła Prawosławnego, przeł. ks. Henryk Paprocki, Kraków, 2001.

Drugi Tydzień Wielkiego Postu, przeł. ks. Henryk Paprocki, http://liturgia.cerkiew.pl/pages/File/docs/n-02-tydzien-paschalny.pdf [dostęp: 13.03.2014 r.]

Katechizm, Warszawa, 1938.

Konstytucje Apostolskie V: 20,4, w: Konstytucje apostolskie oraz Kanony Pamfilosa z apostolskiego synodu w Antiochii, Prawo kanoniczne świętych Apostołów, Kary świętych Apostotów dla upadtych, Euchologion Serapiona, przeł. Stanisław Kalinkowski, Kraków, 2007.

May 27: Holy Pentecost, dostęp on-line: https://oca.org/liturgics/ service-texts

NIEDZIELA ŚWIĘTEJ PIĘĆDZIESIĄTNICY, thum. Ks. Henryk Paprocki, dostęp on-line: http://www.liturgia.cerkiew.pl/pages/File/docs/festum-25-zeslanie.pdf

OFFICE DE LA PENTECOTTE, dostęp on-line: http://orthodoxie. typepad.com/ficher/pentecote_slfr.pdf

Параклет, w: Словарь Библейского Богословия http://krotov. info/spravki/essays_bible/comments/15p.htm\#p3 [dostęp: 26.07.2012 r.];

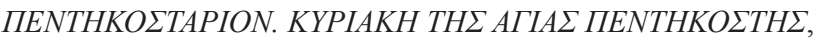
dostęp on-line: http://www.christopherklitou.com/pentecostarion_sunday_of_pentecost_greek.htm

Synaksarion Niedzieli Świętej Pięćdziesiątnicy [przeł. ks. Henryk Paprocki], http://www.liturgia.cerkiew.pl/pages/File/docs/ on-37-piecdziesiatnica.pdf [dostęp: 20.09.2012 r.]

Szawuot, w: Internetowa Encyklopedia PWN, http://encyklopedia. pwn.pl/haslo/3982604/szawuot.html [dostęp: 13.08.2012 r.]

Rozmiar artykułu: 1,1 arkusza wydawniczego 


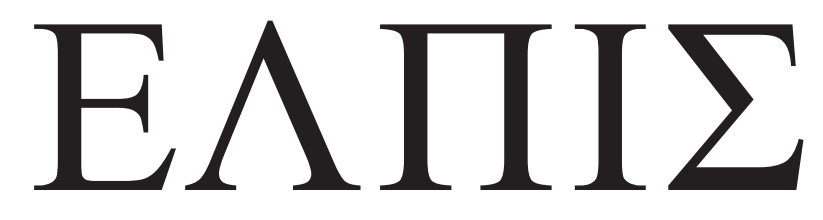

CZASOPISMO TEOLOGICZNE KATEDRY TEOLOGII PRAWOSŁAWNEJ UNIWERSYTETU W BIAŁYMSTOKU

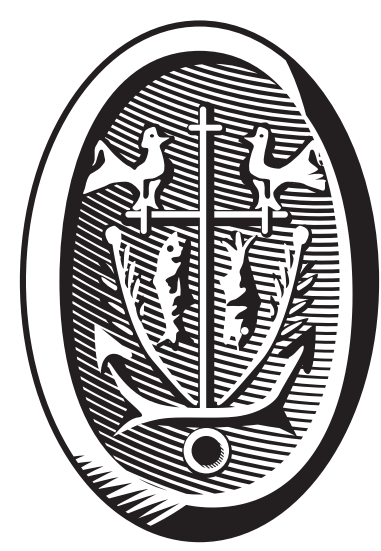

ADRES REDAKCJI

ul. Ludwika Zamenhofa 15, 15-435 Białystok, Polska tel. 85 745-77-80, e-mail: elpis@uwb.edu.pl www.elpis.uwb.edu.pl 